\title{
Determinants of smallholder teff farmer's chemical fertilizer technology adoption in Southern Ethiopia, in case of Gena District in Dawro Zone (Heckman Two-Stage Model)
}

\author{
Deresse Dalango ${ }^{1}$; Tekilu Tadesse ${ }^{2 *}$ \\ 1) Department of Economics, Wolaita Sodo University, Ethiopia \\ ${ }^{2)}$ Department of Economics, Jimma University, Ethiopia \\ *To whom correspondence should be addressed. Email: deredalango.bb@gmail.com
}

\begin{abstract}
s
Increasing technology adoption among smallholder farmers has a big potential to uplift living standards of poor through increasing production and consumption pattern. The objective of this study was analyzing determinant of smallholder teff farmer's chemical fertilizer technology adoption and its intensification in Southern Ethiopia, in case of Gena district in Dawro Zone. The study used data from 180 respondents from four selected teff dominant kebeles of Gena districts in Dawro Zone, through structured questioner. The descriptive statistics and Heckman two stage econometric methods were employed to analyze data collected from sampled household. The significance of coefficient of inverse Mill's ratio $(\lambda)$ indicates the presence of selection bias and the effectiveness of applying Heckman two stage model. In the $1^{\text {st }}$ stage of probit regression results of study show that the adoption decision of chemical fertilizer use were driven by factors such as farm size, size of family, family labor, education, access to credit; access to information, distance to near market place. In the second stage, the intensification of chemical fertilizer application was influenced by membership to cooperative, availability of extension service, access to credit, size of farm land, size of family member, family labor, educational status, sex of head. The policies which expand the accessibility of credit service, dissemination of productive agricultural technology information, and creating opportunity of education for farm house hold has potential to increase the chance of chemical fertilizer adoption decision and strengthen the level of adoption among smallholder farmers.
\end{abstract}

Keywords: Gena, Heckman two stage, Smallholder, Technology adoption

JEL Classifications: D04, D12, D22, D90

\section{INTRODUCTION}

Agriculture plays an important role in economic growth, enhancing food security and poverty reduction in most of developing world. Smallholder agriculture is identified as a vibrant development tool for achieving Millennium Development Goals, one of which is to split the people suffering from extreme poverty and hunger by 2015 (World Bank, 2008).

The Smallholders considered more than 80 per cent of the world's estimated 500 million small farms and afford over 80 per cent of food items consumed in a large part of under developed world, contributing significantly to poverty reduction and food security 
(UNEP, 2013). They harvest foodstuff and non-food products on a small scale with inadequate external inputs, cultivating field and tree crops as well as livestock, fish and other aquatic organisms. However majority of smallholder farmers relies on traditional methods of production and this has lowered the level of productivity. For instance, over $70 \%$ of the maize production in the majority of developing countries is from smallholders who use traditional methods of production (Muzari, Gatsi \& Muvhunzi, 2012). These farmers generally obtain very low crop yields because the local varieties used by farmers have low potential yield, most of the maize is grown under rain-fed conditions and irrigation is used only in limited areas, little or no fertilizers are used and pest control is not adequate (Muzari, Gatsi \& Muvhunzi, 2012; Shao, 1996).

Increasing agricultural productivity is critical to meet expected rising demand and, as such, it is instructive to examine recent performance in cases of modern agricultural technologies (Challa, 2013). Agricultural technologies include all kinds of improved techniques and practices which affect the growth of agricultural output (Jain, Arora \& Raju, 2009). According to Lavison (2013) the most common areas of technology development and promotion for crops include new varieties and management regimes; soil as well as soil fertility management; weed and pest management; irrigation and water management. By virtue of improved input/output relationships, new technology tends to raise output and reduces average cost of production which in turn results in substantial gains in farm income (Challa, 2013). Adopters of improved technologies increase their productions, leading to constant socio-economic development. Adoption of improved agricultural technologies has been associated with: higher earnings and lower poverty; improved nutritional status; lower staple food prices; increased employment opportunities as well as earnings for landless laborers (Kasirye, 2010). On the other hand, non-adopters can hardly maintain their marginal livelihood with socio-economic stagnation leading to deprivation (Jain, Arora \& Raju, 2009, 2009).

In low income countries, improving the livelihoods of rural farm households via agricultural productivity would remain a mere wish if agricultural technology adoption rate is low (Ajayi, Franzel, Kuntashula, \& Kwesig, 2003). A new farm technology adoption has direct effect on the farmer's income resulting from higher yields and prices (Ibrahim, Mustapha \& Nuhu, 2012). Therefore, it is necessary to adopt the recognized agricultural technologies so as to enhance production as well as productivity and thereby the living condition of the rural poor. The procurement and distribution of agricultural inputs more particularly high yield varieties and chemical fertilizer have been the central solution to enhance crop production and productivity so as to improve the living standards of farm households. This thought is crucial for countries like Ethiopia whose people heavily rely on subsistence farming. In line with this idea, different literatures were review regarding to the amount of agricultural inputs which have been applied to increase the production and productivity of teff in Ethiopia. For instance, the study by Engdawork (2009) identified that teff productivity depends on good weather condition and use of appropriate technologies (fertilizer, improved seed, and herbicide) with the recommended rate and time.

However, the adoption of productive technology very low with smallholder farmers and it is varying from farmer to farmer based on farmer's skill and external factors. This is similar with the report made by international finance corporation, to whom the adoption level of improved technology vary widely among smallholder farmers depending on their ability to invest in production. For example, the fertilizer adoption is near zero in some African countries, while it exceeds $500 \mathrm{~kg}$ per hectare in China and Egypt (IFC, 2013). 
The adoption of more efficient farming practices and technologies that enhance agricultural productivity and improve environmental sustainability is also varying from place to place in Ethiopia. In central part of the country, there is relatively good practice but in peripheral part there is very low adoption resulting low productivity and stagnant life of farm family. This articulate the need for investigation to analyze demographic, socio-economic and institutional factors hindering the smallholder farmers technology adoption in crop potential area like Gena district of Dawro zone in south nation nationality and peoples regional state. Contrasting to its natural endowment, the crop commercialization in area was the lowest relative to other areas in South nation nationality and people's regional state (JICA, 2012). This show its low productivity resulted from low application or improper application of improved technology. In addition, there was no research has been done concerning the hindering factors of their low technology adoption. Hence, it needs empirical analysis to verify the factors responsible for low status of chemical fertilizer adoption in study area. Therefore, this study was designed to identify demographic, institutional and socio-economic factors that determine the smallholder teff farm house hold chemical fertilizer adoption decision and extent of adoption.

\section{LITERATURE REVIEW}

New technology adoption is a decision-making process in which an individual passes from first knowledge of an innovation, to forming an attitude toward an innovation, to a decision to adopt or reject, to implementation of new idea, and to confirmation of the decision (Ray, 2001). Agricultural technology adoption states to the decision to use a new technology, method, practice, etc. by a farmer (Feder, Just \& Zilberman, 1985). On the other hand, extent of technology adoption is defined as the level of adoption of a given technological package among user (Nkonya, Schroeder \& Norman, 1997). The expansion of new agricultural technology application has increased agricultural productivity, contributed to overall economic growth, and reduced food insecurity and poverty in developed and some developing countries (Bandeira \& Rasul, 2005; Cornejo \& McBridgje, 2002).

Different research on technology adoption across various region witness that demographic, institutional and socio-economic factor affects the farm house hold decision to adopt new technology and its intensification. Using panel probit and bivariate probit model in Malawi, Holden \& Lunduka (2012), found that households with more livestock endowment and off/non-farm income were applying significantly more fertilizer on their plots, showing the importance of wealth for accessing fertilizer. According to Ermias (2013), the farmer's adoption decision and intensity of use of improved sorghum varieties were positively influenced by irrigated farm size, tropical livestock unit, farmers' perception of yielding capacity and taste preference for improved sorghum varieties while active labor ratio, distance from farmers training center to home, proportion of sorghum farm from the total cultivated land and farm size had negative and significant influence on both the probability and intensity of adopting improved sorghum varieties.

Moreover, Kapalasa (2014) examined the significant influence of demographic, socio-economic and Institutional factors such as age, access to extension services and distance to the nearest market of the household on farmers' decision to adopt and intensity use of improved soybean varieties. This study also found the negative influence of age of family head on the probability of adoption of new technologies. Bayissa (2014), applying double-hurdle model in East Wollega Zone examined that both adoption and 
intensity use of improved teff were positively and significantly influenced by sex of the household head, farming experience, participation on crop production training, educational level, yield superiority and maturity period of new varieties but the distance to the nearest market place had negative influence on the adoption and intensity use of improved technology.

\section{METHODS}

\section{Description of the study area}

This study was take place in South nation, Nationality and people's regional state Gena district of Dawro Zone, in South Nations, Nationalities, and Peoples' Regional state (SNNPR). Dawro zone lies in between $6^{0} 36^{\prime}$ to $7^{0} 21^{\prime}$ north latitudes and $36^{\circ} 68^{\prime}$ to $37^{0}$ 52 ' east longitudes. The Gojeb and Omo Rivers circumscribe and demarcate Dawro from northwest to southwest in a clockwise direction. Dawro shares boundaries with Konta Special Wereda in west, Jimma in northwest, Hadiya and Kambata-Tambaro zones in northeast, Wolayita zone in east, and Gamo-Gofa zone in southeast. It has eleven administrative district and one town administration. The political center of the zone is Tarcha, which is located in $486 \mathrm{~km}$ from south western of Addis Ababa through Jimma road, and $282 \mathrm{~km}$ from Hawassa.

The climatic condition of the Gena district divided in to thee including Dega, Woina-dega and kola. Agriculture is the predominant economic activity in the Gena district. Crop and livestock production is the main household activities and the basis of subsistence in district. Rain fed mixed farming is practiced in all parts of the district i.e. livestock husbandry and crop production entirely practiced and irrigation (flood) farming practiced in very few area. Due to agricultural dependence on rain water, many crops are planted during rainy seasons (meher). The dominant cereal crops like maize, teff and wheat produced in meher season and collected from October to December. Major crops produced in the area include maize, teff, wheat, barley, sorghum, pulses, enset etc.

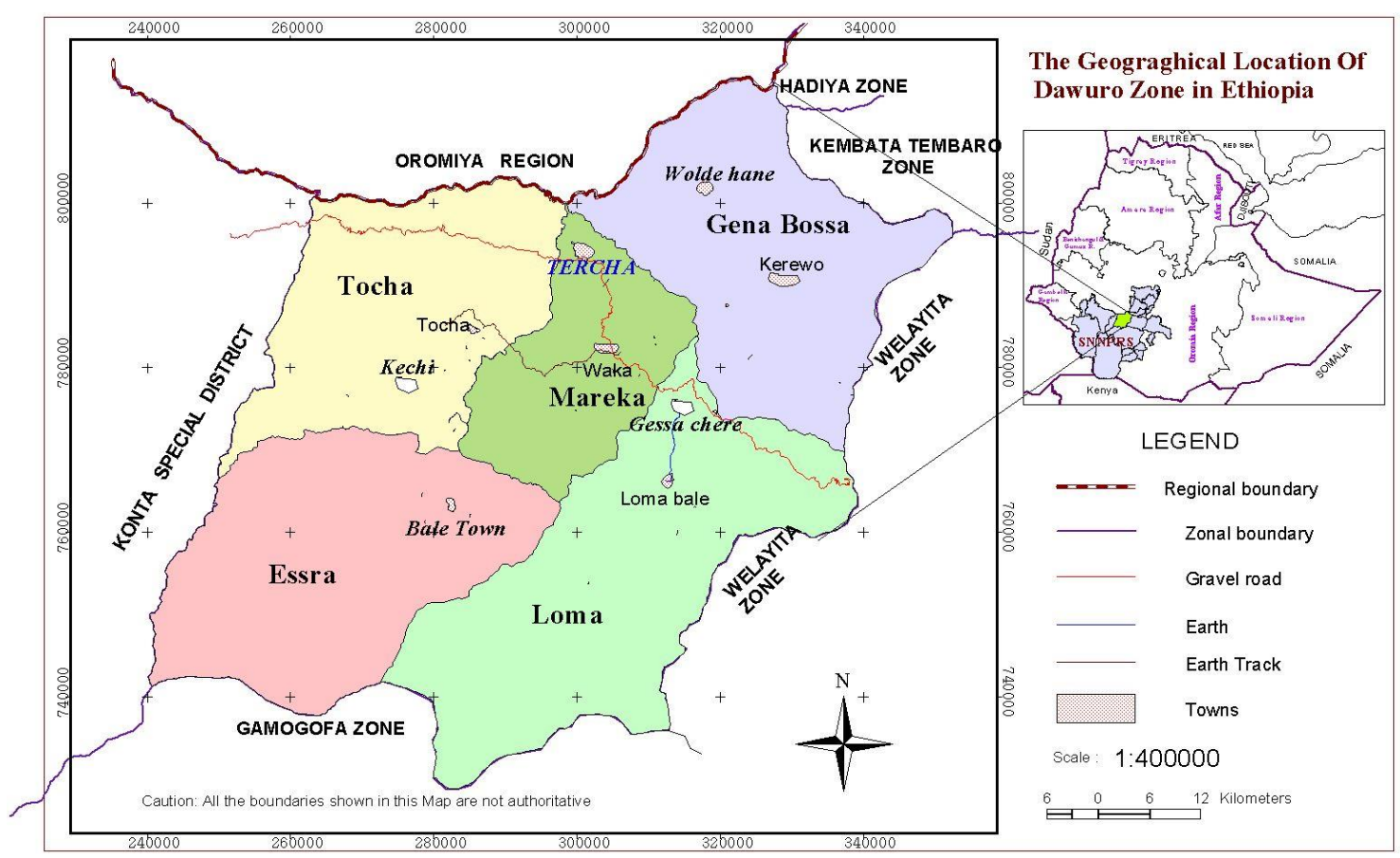

Figure1. The Location of Gena district in Ethiopia 


\section{Research strategy}

In this inquiry, both quantitative and qualitative research strategies was employed. The quantitative strategy used to investigate the data that was collected using structured questionnaire from 180 sampled farm household heads. The qualitative research strategy used to analyze data that was collected using the unstructured interviews with local traders; rural experts; kebele administrative body; and consumers to capture supplementary information and to observe the validity of information's from household survey.

\section{Research design}

The cross-sectional (survey) research design was applied in this study. Accordingly, demographic, socio-economic and institutional data related to chemical fertilizer application status of smallholder farm family was collected for the harvest year of 2018/19 and analyzed through econometric and descriptive methods.

\section{Sample size determination}

The samples for this study distinguished according to the formula for sample size determination for finite population given by Kothari (2004) as shown below;

$n=\frac{z^{2} \cdot p \cdot q \cdot N}{e^{2}(N-1)+Z^{2} \cdot p \cdot q}$

Where:

$\mathrm{n}=$ stands for estimated sample size,

$\mathrm{E}=$ the allowable error;

$\mathrm{N}=$ number of population under the study;

$\mathrm{p}=$ sample proportion of successes;

$\mathrm{q}=1-\mathrm{p}$;

$\mathrm{z}=$ standard variate for given confidence level (as per normal curve area). It is 1.96 for a $95 \%$ confidence level.

Assuming confidence level 95.5\%; $\mathrm{N}=1262 ; \mathrm{e}=0.02 ; \mathrm{z}=2.05 ; \mathrm{p}=0.02$ and $\mathrm{q}=1-0.02$ we can have the following:-

$n=\frac{(2.05)^{2} \times 0.02 \times(1-0.02) \times 1262}{(0.02)^{2} \times(1262-1)+(2.05)^{2} 0.02 \times(1-0.02)}=\frac{103.9496}{0.5867} \cong 177$.

Hence, 177 respondents rounded off to 180 to enable the distribution of the sample in to four selected kebele.Based on the size of farm household in each kebele these 180 potential respondentswere designated.

Table 1. The list of selected kebeles and sample size in each study site

\begin{tabular}{lcccc}
\hline \multirow{2}{*}{ Selected site } & \multicolumn{2}{c}{ No. of farm household in kebele } & Sampled \\
\cline { 2 - 4 } respondent
\end{tabular}

Source: survey data (2018/19)

\section{Methods of data analysis}

In this study the descriptive statistics such as mean, standard deviation, percentages, frequency, t- test, Chi-square and graphs were used in analyzing the data. Furthermore, it was assumed that smallholder farmers who cultivate teff may or may not apply chemical 
fertilizer in teff cultivation. Therefore, the dependent variable in this model is discrete consisting of two outcomes, yes or no. In this case, the use of Ordinary Least Square/OLS technique for such variables poses inference problems, and thus not appropriate for investigating dichotomous or limited dependent variables. In such circumstances, maximum likelihood estimation procedures such as logit or probit models are generally more efficient (Gujarati, 1995).

Several investigators used different models for analyzing the determinants of technology adoption at farm level. Various adoption studies have used Tobit model to estimate adoption relationships with limited dependent variables while the others used double-hurdle model. However, it is conceivable to use Heckman's (1979) two step procedure in case of anticipated problem of selection bias in the sample. Selection bias was anticipated in this study because among the representative not all households are believed to participate in fertilizer adoption due to individual problems.

The Heckman two-step selection model allows for separation between the initial decision to adopt technology ( $Y>0$ versus $Y \leq 0)$ and the level of their application. The model uses in the first step a probit regression to assess the probability of decision to adopt and in the second step uses ordinary least squares (OLS) to determine the intensity of adoption (Green, 2007) and the method correct sample selection bias. This technique used in order to control the selectivity bias and endogeneity problem and to obtain consistent and unbiased parameter estimates (Green, 2007). In selection model procedure, sample bias is determined by the relationship between the residuals of the two stages (stage 1 and stage 2). Estimates are biased if the residuals in the stage 1 and 2 are correlated. Similarly, Stage 1 does not affect stage 2 results if the residuals are unrelated. Positive and negative correlations between residuals are indicated respectively, by positive and negative mu $(\mu)$ values, which is the correlation between error terms of two regression model.

The first stage Heckman two step or the probit model that analyze the factors determining the probability of chemical fertilizer adoption decision specified as:

$\operatorname{pr}\left(Y_{1 i}=1 / x_{1 i}, \beta_{1 i}\right)=\Phi\left(f\left(x_{1 i}, \beta_{1 i}\right)\right)+\varepsilon_{i}$

Where; $Y_{1 i}$ is an indicator variable that is equal to unity for chemical fertilizer user households; $\Phi$ is the standard normal cumulative distribution function; $x_{1 i}$ is variable that affect adoption decision and was described in table $3.2 ; \beta_{1 i}$ is a coefficient to be estimated. The variable $Y_{1 i}$ takes the value 1 if the household use chemical fertilizer and zero otherwise. This can be shown mathematically:-

$Y_{1 i}^{*}=\beta_{0}+\beta_{1 i} X_{1 i}+\varepsilon_{i}$

Where; $i=1,2,3 \ldots \ldots \ldots \ldots \ldots . . n$

$Y_{1 i}= \begin{cases}1 & \text { if } Y_{1 i}^{*}>0 \\ 0 & \text { if } Y_{1 i}^{*} \leq 0\end{cases}$

$Y_{1 i}^{*}$ is a latent variable of marginal utility the farmer's get from adoption of chemical fertilizer input,

$\beta_{0}$ is Constant term,

$\varepsilon_{i}$ is error terms in the first stage model assumed to be normally distributed with zero mean and constant variance $\left(\sigma^{2}\right)$.

In the second stage parameters can consistently be estimated by OLS by incorporating an estimate of the inverse Mills ratios denoted as $\lambda_{i}$ from probit regression model as additional explanatory variable as specified bellow:-

$Y_{2 i}=\alpha_{0}+\alpha_{i} X_{2 i}+\mu_{i} \lambda_{i}+v_{i}$ 
Where:

$Y_{2 i}=$ is the quantity fertilizer applied per hector,

$X_{2 i}=$ implies the explanatory variables influencing the level of chemical fertilizer applied shown in table 3.2 ,

$\alpha_{0}=$ is the Constant term in OLS regression model,

$\alpha_{i}=$ is the Parameters to be estimated in the second stage,

$\lambda_{i}=$ is the inverse mills ratio computed from first stage estimation,

$\mu_{i}=$ implies the Correlation between first and second stage error terms or corr $\left(\varepsilon_{i}, v_{i}\right)$,

$v_{i}=$ is the error terms in the second stage.

According to Heckman (1979), the IMR $\left(\lambda_{i}\right)$ is a variable for controlling bias due to sample selection. This term is constructed using the model in the probit regression (first stage) and then incorporate into the model of the second stage (OLS) as an independent variable. It can obtained:-

$\lambda_{i}=\frac{\phi\left(\beta_{0}+\beta_{1 i} X_{1 i}\right)}{\Phi\left(\beta_{0}+\beta_{1 i} X_{1 i}\right)}$

Where, $\phi($.$) denotes the standard normal probability density function and \Phi($.$) denotes$ the cumulative distribution function for a standard normal random variable.

But the value of $\lambda_{i}$ is not known, the parameters $\beta_{0}$ and $\beta_{1 i}$ can be estimated using a probit model, based on the observed binary result. Then the estimated IMR calculated as:-

$\widehat{\lambda_{l}}=\frac{\phi\left(\widehat{\beta_{0}}+\widehat{\beta_{1 l}} X_{1 i}\right)}{\Phi\left(\widehat{\beta_{0}}+\widehat{\beta_{1 l}} X_{1 i}\right)}$

\section{Hypotheses and justification of explanatory variables}

One of the important parts in this section is to specify and hypothesize the dependent and explanatory variables that were used in the model. Regarding to its definition, measurement and hypotheses of variables, which was used in our model, summarized in the Table 2.

Table 2. Explanation of hypothesized effect of explanatory variables on chemical fertilizer adoption and its intensity

\begin{tabular}{|c|c|c|c|}
\hline Variable & $\begin{array}{l}\text { Nature of } \\
\text { variable }\end{array}$ & Variable definition and measurement & $\begin{array}{r}\text { Expected } \\
\text { effect }\end{array}$ \\
\hline $\begin{array}{l}\text { Fertilizer adoption } \\
\text { decision }\end{array}$ & Binary & $\begin{array}{l}1 \text { if household use chemical fertilizer, } 0 \\
\text { otherwise. }\end{array}$ & \\
\hline $\begin{array}{l}\text { Quantity of fertilizer } \\
\text { applied }\end{array}$ & Continuous & Fertilizer in kg per hector & \\
\hline $\begin{array}{l}\text { Age of the farm } \\
\text { household head }\end{array}$ & Continuous & Age of the household head in year & $-/+$ \\
\hline Farm size & Continuous & Farm land size in hectare & + \\
\hline Household labor & Continuous & $\begin{array}{l}\text { household labor force or number of } \\
\text { family in working age }\end{array}$ & + \\
\hline Size of family & Continuous & number of family members & - \\
\hline Distance to the market & Continuous & $\begin{array}{l}\text { Distance from selected farm household to } \\
\text { the market place in } \mathrm{Km}\end{array}$ & - \\
\hline Sex of farm head & Dummy & $\begin{array}{l}\text { sex of farm household head (if female }=1 \text {, } \\
0, \text { otherwise) }\end{array}$ & - \\
\hline $\begin{array}{l}\text { Educational status of the } \\
\text { household head }\end{array}$ & Dummy & $\begin{array}{l}\text { Educational status of the household } \\
\text { head( } 1 \text { literate, } 0 \text {, otherwise) }\end{array}$ & + \\
\hline $\begin{array}{l}\text { Participation in nonfarm } \\
\text { activity }\end{array}$ & Dummy & $\begin{array}{l}\text { participation in nonfarm activity(if have } \\
=1,0 \text {, otherwise) }\end{array}$ & $-/+$ \\
\hline
\end{tabular}




\begin{tabular}{|c|c|c|c|}
\hline Variable & $\begin{array}{l}\text { Nature of } \\
\text { variable }\end{array}$ & Variable definition and measurement & $\begin{array}{r}\text { Expected } \\
\text { effect }\end{array}$ \\
\hline Road condition & Dummy & $\begin{array}{l}\text { Road condition to nearby town (if } \\
\text { Good }=1,0 \text {, Otherwise) }\end{array}$ & + \\
\hline $\begin{array}{l}\text { Membership of } \\
\text { cooperative }\end{array}$ & Dummy & $\begin{array}{l}\text { Households membership to coope-rative } \\
\text { (if member Yes }=1,0 \text { Otherwise) }\end{array}$ & + \\
\hline Access to extension & Dummy & $\begin{array}{l}\text { Access to extension agent support (if } \\
\text { have access Yes }=1,0 \text { Otherwise) }\end{array}$ & + \\
\hline Use of credit & Dummy & use of credit (having access $=1,0$, otherwise & + \\
\hline Access to information & Dummy & $\begin{array}{l}\text { access to new technology adoption skill } \\
\text { (having inf. }=1,0 \text {, otherwise) }\end{array}$ & + \\
\hline
\end{tabular}

Source: Authors hypothesis (2018/19)

\section{RESULT AND DISCUSSION}

\section{Descriptive analysis}

Out of total sample of 180 smallholder teff farm household, 135(75\%) participated in adoption of chemical fertilizer in their cultivation, while the remaining $45(25 \%)$ were no practicing fertilizer technology. Table 3 illustrate the mean, minimum and maximum age of head, size of land ownership, distance to market center, number of family and family labor for total survey, fertilizer adopter and non-adopter in comparison.

The descriptive statistics result for continuous variable (Table 3, t-value) show that there was no statistically significant difference between fertilizer adopter and non-adopter concerning age of head, family size and distance to local town or market place while there was significant difference in land holding and handiness of family labor. This demonstrates the importance of family labor force and arable land whether the household to adopt or not to adopt productive technology.

Table 3. Description of continuous variables

\begin{tabular}{|c|c|c|c|c|c|c|c|c|c|c|}
\hline \multirow{2}{*}{ Variables } & \multicolumn{3}{|c|}{ Participant(N=135) } & \multicolumn{3}{|c|}{ Non-participant $(\mathrm{N}=45)$} & \multicolumn{3}{|c|}{ Total $(\mathrm{N}=180)$} & \multirow{2}{*}{$\mathrm{t}$-value } \\
\hline & Mean & Min. & Max. & Mean & Min & Max. & Mean & Min. & Max. & \\
\hline Age of $\mathrm{HH}$ & 47.22 & 26 & 82 & 47.02 & 28 & 75 & 47.17 & 26 & 82 & 0.0955 \\
\hline $\begin{array}{l}\text { Size of land } \\
\text { holding }\end{array}$ & 3.03 & 1 & 5 & 2.29 & 0.5 & 5 & 2.84 & 0.5 & 5 & $3.5251 * * *$ \\
\hline Size of family & 7.4 & 3 & 13 & 7.68 & 4 & 13 & 7.47 & 3 & 13 & 0.7219 \\
\hline $\begin{array}{l}\text { Size of active } \\
\text { family }\end{array}$ & 3.54 & 1 & 8 & 3.07 & 2 & 10 & 3.42 & 1 & 10 & $1.8941^{* *}$ \\
\hline $\begin{array}{l}\text { Distance to local } \\
\text { town }\end{array}$ & 8.47 & 6 & 13 & 9.29 & 6 & 13 & 8.68 & 6 & 13 & 2.8332 \\
\hline
\end{tabular}

***, ** and * imply statistically significant at 1, 5 and $10 \%$ respectively.

Source: Own survey data (2018/19)

Table 4.summarizes frequency, percentage and level of influence of dummy variable. Accordingly, there was statistically significant difference between fertilizer adopter and non-adopter in education level of head, membership to cooperative, affordability of credit and access to information. On the other hand, the difference between chemical fertilizer adopter and non-adopter is not significant in gender, obtaining extension service and participation of off-farm activity. 
Table 4. Description of dummy variables

\begin{tabular}{|c|c|c|c|c|c|c|}
\hline \multirow[t]{2}{*}{ Variables } & & \multicolumn{2}{|c|}{ Participant } & \multicolumn{2}{|c|}{ non- participant } & \multirow[b]{2}{*}{$\mathrm{t}$-value } \\
\hline & & Frequency & Percent & Frequency & Percent & \\
\hline \multirow{2}{*}{$\begin{array}{l}\text { Had female headed } \\
\text { family }\end{array}$} & Yes & 16 & 11.85 & 17 & 37.78 & \multirow{2}{*}{$(4.0448)$} \\
\hline & No & 119 & 88.15 & 28 & 62.22 & \\
\hline \multirow{2}{*}{$\begin{array}{l}\text { The family headed } \\
\text { was literate }\end{array}$} & Yes & 70 & 51.85 & 3 & 6.67 & \multirow{2}{*}{$5.7966 * * *$} \\
\hline & No & 65 & 48.15 & 42 & 93.33 & \\
\hline \multirow{2}{*}{$\begin{array}{l}\text { Participate in non- } \\
\text { farm activity }\end{array}$} & Yes & 28 & 20.74 & 8 & 17.78 & \multirow{2}{*}{0.4282} \\
\hline & No & 107 & 79.26 & 37 & 82.22 & \\
\hline \multirow{2}{*}{$\begin{array}{l}\text { Have member to } \\
\text { cooperative }\end{array}$} & Yes & 47 & 34.81 & 6 & 13.33 & \multirow{2}{*}{$2.7813 * * *$} \\
\hline & No & 88 & 65.19 & 39 & 86.67 & \\
\hline \multirow{2}{*}{$\begin{array}{l}\text { Have access to } \\
\text { extension }\end{array}$} & Yes & 123 & 91.11 & 39 & 86.67 & \multirow{2}{*}{0.8576} \\
\hline & No & 12 & 8.89 & 6 & 13.33 & \\
\hline \multirow[t]{2}{*}{ Have access to credit } & Yes & 49 & 36.30 & 5 & 11.11 & \multirow{2}{*}{$3.2689 * * *$} \\
\hline & No & 86 & 63.70 & 40 & 88.89 & \\
\hline \multirow{2}{*}{$\begin{array}{l}\text { Have access to } \\
\text { information }\end{array}$} & Yes & 45 & 33.33 & 1 & 2.22 & \multirow{2}{*}{$4.3325^{* * *}$} \\
\hline & No & 90 & 66.67 & 44 & 97.78 & \\
\hline
\end{tabular}

***, ** and * imply statistically significant at 1\%, 5\% and $10 \%$ respectively.

Source: Own survey data (2018/19)

\section{An econometric estimation results}

In this sub-section, Heckman two stage selection analyses is executed to identify the household-level demographic, socio-economic and institutional factors that determine the decision of smallholder farmers to adopt or not to adopt chemical fertilizers in the first stage by applying probit regression. In the second stage the conditional estimation/OLS method was used to investigate factors that influence the level of their adoption.

However, before running the regression analysis, the diagnostic tests, such that, the existence of multicollinearity and the problem of heteroscedasticity of variables included in the model are needed to be checked both for the continuous and discrete explanatory variables. According to Gujarat (2004), when the values of VIF approach to infinitive there is serious problem of multicollinearity, while if VIF is below 10 there is no much problem. In this study all the computed value of VIF for explanatory including IMR variable was blow five. Therefore, there is no evidence of multicollinearity problem in our model. The data were tested for heteroscedasticity using the Breusch-Pagan test (Wooldridge, 2012). The Breusch-Pagan test evaluates the null hypothesis of a constant variance in the data. The Chi-square value results of STATA output were presented in appendix--. Accordingly, the null hypothesis of a constant variance was not rejected implying absence of heteroscedasticity in survey data.

\section{Factors determining smallholder teff farmers' chemical fertilizer technology adoption decision}

Table 5. shows the probit regression and marginal effect of probit outcomes of factors that influence the likelihood of small teff farmers' technology adoption decision. The models constructed with 13 independent variables and out of these 8 variables are significantly determining the adoption decision with hypothesized sign. These variables include size of farm land, size of family, availability of family labor force, education status of household head, accessibility of credit service ; access to modern technology information, distance to near town and nearby road condition significantly affect the teff farmers' technology adoption decision. Whereas, age of household head; participation in off-farm activity; sex of household head; membership to farm cooperative and access to 
agricultural extension service insignificantly but all variables with expected sign influence the technology adoption decision.

Table 5. Factors that determine teff farmers' chemical fertilizer technology adoption decision Probit model result

\begin{tabular}{|c|c|c|c|c|c|c|}
\hline \multirow[b]{2}{*}{ Variables } & \multicolumn{3}{|c|}{ Parametric estimation } & \multicolumn{3}{|c|}{ Marginal effect } \\
\hline & Coefficient & Std. Err. & $Z$ & $\begin{array}{l}\text { Coefficient/dF } \\
\qquad / \mathrm{dx}\end{array}$ & Std. Err. & $\mathrm{P}>|\mathrm{z}|$ \\
\hline Age of $\mathrm{HH}$ & -.000669 & .0114707 & -0.06 & -.0001013 & .0017342 & 0.953 \\
\hline Size of farm land & .2833829 & .1361792 & 2.08 & $.0429217 * *$ & .0222735 & 0.037 \\
\hline Size of family & -.20539 & .0697466 & -2.94 & $-.0311087 * * *$ & .0125296 & 0.003 \\
\hline Size of family labor & .314829 & .1209661 & 2.60 & $.0476846 * * *$ & .0194406 & 0.009 \\
\hline Distance to nearby town & -.2330726 & .0856155 & -2.72 & $-.0353016^{* * *}$ & .0151054 & 0.006 \\
\hline Sex of $\mathrm{HH}$ & -.3871656 & .3162718 & -1.22 & -.0692904 & .068749 & 0.221 \\
\hline Education status of $\mathrm{HH}$ & 1.030386 & .376136 & 2.74 & $.1425391 * * *$ & .0579773 & 0.006 \\
\hline Off-farm activity & .0719233 & .3476857 & 0.21 & .0105712 & .0498617 & 0.836 \\
\hline Road condition & -.6056992 & .3149832 & -1.92 & $-.0938703 *$ & .0544667 & 0.054 \\
\hline Membership to coop. & .1774871 & .3801732 & 0.47 & .0255694 & .0523672 & 0.641 \\
\hline Access to extension & .4178456 & .4081969 & 1.02 & .0790363 & .0929736 & 0.306 \\
\hline Access to credit & 1.035122 & .4084254 & 2.53 & $.122643^{* *}$ & .047505 & 0.011 \\
\hline $\begin{array}{l}\text { Access to input } \\
\text { technology info. }\end{array}$ & 1.753076 & .6617307 & 2.65 & $.1691507 * * *$ & .0460535 & 0.008 \\
\hline Constant & 1.845224 & 1.087742 & 1.70 & - & - & - \\
\hline
\end{tabular}

As specified in Table 5., the marginal effect report of the probit regression provides the probability that a farm household able to adopt technical input particularly chemical fertilizers in their teff production.

The farm size of respondent was positive and had statistically significant influence at $5 \%$ level on the adoption of chemical fertilizer input. The marginal effect result indicates that a farmer, who has one additional hector of arable land, would increase the likelihood of teff farmers' chemical fertilizer adoption by $4.29 \%$. This result is in line with the argument of Nowak (1987), which claimed that larger arable land ownership enable farmers to have more flexible in their decision making, greater access to discretionary resource, and give more opportunity to adopt new farm practice. This is due to the fact that availability of more arable land enable farmers' to allocate more land to produce teff crop leading increment in output and the rise in output widen the chance of farmers' more income and the increment in family income enable farmers to widen the understanding and use of new technology.

As hypothesized, distance to the nearest town was found to be negatively and significantly influenced the probability of adoption of chemical fertilizer adoption decision at $1 \%$ significance level. Holding other variables constant, a kilometer increase from farmers' residence to near town leads 3.5\% reduction on the likelihood of adoption of chemical fertilizer on teff cultivation. This implied that the longer the distance between farm basis and the market place, the lower will be the probability of adoption of fertilizer input. Farmers who dwell around town or local market center might have more chance to 
access information about new agricultural technology and input. Moreover, nearness to market place reduce the transportation and other transaction costs out lied in search for fertilizer input and then reduce cost of production than those farmers who are in distant location. This finding is similar with Susie (2017), Bessir (2014) and Debelo (2015). According to their finding an increase in distance from market center increases transaction costs related to the sale of farm output and purchases of critical input that would reduce farmers' motivations to engage in agricultural production activities using improve technologies.

In the same genre, the nearby road condition found the expected negative influence and is significant at $10 \%$ level, on the probability of adoption of chemical fertilizer in teff production. Keeping other variables constant, compared with farmers who have good roads on the spot, those farmers who have no accessible road infrastructure reduce the probability of chemical fertilizer adoption by $9.5 \%$.

As expected, the availability of family labor force have positive impact on likelihood of teff farmers' chemical fertilizer adoption at significance level of below $1 \%$. The marginal effect verify that the availability of one more active person in family increase the probability of chemical fertilizer input adoption on teff cultivation by 4.67 $\%$, holding all other factors constant. This finding is consistent with the results of Beshir, Emana, Kassa, \& Haji (2012), which reason out that improved farm practices are labour intensive and hence the household with relatively high labour force uses the technologies on their farm plots better than those with little labour force in family. In contrary, the size of family is negatively related with the probability of fertilizer adoption at $1 \%$ level of significance. A one additional person in family member results, $3.11 \%$ decline in likelihood of farm household fertilizer adoption. The large family is expected to consume the higher quantity of crop compared to small family, causing smaller amount of marketable surplus with low level of family income.

As hypothesized, education level of household head was found to be positively and significantly influenced the probability of adoption of chemical fertilizer input in teff cultivation. Holding other variables constant, as compared to illiterate farmers the probability of adoption of fertilizer input in teff production for literate farmers would increase by $14.25 \%$. This indicates that the educated farmers are more confident to adopt fertilizer input in their cultivation than those who are illiterate. Farmer with formal education have better ability to obtain information's about productive input and new technology of production relative to uneducated one. Education also increase decision making ability of farmers based on identified information of cost and benefit. This result is consistent with work of Bayissa (2014) and Leake \& Adam (2015), they forwarded that having education increases the probability of adoption of new agricultural technology by farmers.

As expected, access to input market information has shown positive influence on likelihood of teff farmers' fertilizer technology adoption decision at $1 \%$ level of significance. Keeping other variables constant, farmers with accessibility to input market information have $16.91 \%$ better opportunity to adopt chemical fertilizer than those with insufficiency of information. Accessible information increase farmers chance to adopt technology because it enables farmers to make right decision how to apply and increase productivity with minimum probability of risk.

Access to credit service also positively determines the probability of teff farmers' fertilizer technology adoption at 5\% level of significance. Keeping other variables fixed, 
availability of credit service encourage the likelihood of household fertilizer technology adoption decision by $12.26 \%$. This result was consistent with finding of Ogada (2013), which reason out that accessible credit solve the smallholders problem created due to their low saving ability to purchase relatively more expensive technologies like inorganic fertilizer. Hence, the accessibility of credit enables farmers to purchase inputs like improved seed, fertilizer, which increase output through productivity increment. On the other hand, accessibility of credit solve farmers cash problem that hinders farmers to purchase chemical fertilizer at early period of crop collection in which there was no sufficient market or low price for agricultural output. Therefore, farmers who have availability of credit service are more likely to adopt chemical fertilizer than without credit.

\section{Factors determining the intensity of teff farm household technology adoption}

The Heckman model in the second stage estimation identifies the factors that determine the intensity of chemical fertilizer adopted using the OLS model. The coefficient of inverse Mill's ratio /Lambda is significant at 5\% level. The significance of Mill's ratio discloses the presence of selection bias and the effectiveness of applying Heckman two stage models due to its ability to handle the selection problem. The positive sign of lambda reflects that the error terms in the adoption decision model and selection equations are positively correlated.

Table 6. reveals that the regression results of variables that affect the level of technology adoption among smallholder farmers. Out of 14 explanatory variables size of farm land, size of family member, the number of family labor force, educational status of house hold head, membership to cooperative, availability of extension service, access to credit, sex of head and lambda significantly influence the intensity of technology adoption, while age of house hold head, the existing road condition, participation in offfarm activity, availability of input information and distance to the nearest town place insignificant to influence the level of adoption.

Table 6. Results of the second-stage selection estimation (intensification of technology adoption)

\begin{tabular}{lllrr}
\hline Variables & Coefficient & \multicolumn{1}{l}{ Std. Err. } & \multicolumn{1}{c}{$\boldsymbol{t}$} & $\mathrm{P}>|\boldsymbol{t}|$ \\
\hline Age of HH & .0078799 & .0069553 & 1.13 & 0.260 \\
Farm land size & $.2404788^{* * *}$ & .0683283 & 3.52 & 0.001 \\
Size of family & $-.1033396^{* * *}$ & .0395494 & -2.61 & 0.010 \\
Family labor & $.1871805^{* * *}$ & .0652871 & 2.87 & 0.005 \\
Distance to near town & -.0596027 & .0492811 & -1.21 & 0.229 \\
Sex of HH & $-.4295681^{*}$ & .2439408 & -1.76 & 0.081 \\
Education of HH & $.4842824^{* *}$ & .1938138 & 2.50 & 0.014 \\
Participation in off-farm activity & -.1551343 & .1817373 & -0.85 & 0.395 \\
Road condition & -.0074408 & .1632477 & -0.05 & 0.964 \\
Membership to coop. & $.468811^{* * *}$ & .1653608 & 2.84 & 0.005 \\
Access to extension & $.5587541^{* *}$ & .2618734 & 2.13 & 0.035 \\
Access to credit & $.575232^{* * *}$ & .1705756 & 3.37 & 0.001 \\
Access to information & .2800549 & .1785002 & 1.57 & 0.119 \\
Mills lambda & $.7250642^{*}$ & .369385 & 1.96 & 0.052 \\
Constant & $1.314168^{*}$ & .6838175 & 1.92 & 0.057 \\
\hline
\end{tabular}

Number of observation $=180$; Censored observation $=45 ;$ Uncensored Observation $=135$;

$R$-squared $=0.4124 ;$ Adj $R$-squared $=0.3439 ; F(14,120)=6.02 ;$ Prob $>F=0.0000$

$* * *, * *$ and $*$ imply statistically significant at 1,5 and $10 \%$ respectively.

Source: Survey data (2018/19) 
Analogous to the first stage result, size of land holding, family size, size of house hold labour, educational status of family head and availability of credit service determine both adoption decision and intensity of adoption significantly with expected sing. Moreover, level of household head education and availability of credit service have the expected positive effect on level of fertilizer adoption at significance level of $5 \%$ and $1 \%$ respectively. The size of family and household labor force determine the intensity of fertilizer adoption by $1 \%$ significance level and have expected negative and positive influence on intensity of adoption respectively. One additional person in family deteriorate the use of fertilizer by $0.10 \mathrm{~kg}$, while one more active labor to family enhance the use of fertilizer by $0.19 \mathrm{~kg}$, holding all other variables constant. Size of land holding also found positive and significant influence on the level of fertilizer adoption at $5 \%$ level. A one hector increase in land holding increase fertilizer applied by $0.24 \mathrm{~kg}$, keeping other variables constant.

As expected, being member to producer group has positively and significantly influences the intensity of fertilizer adoption at $1 \%$ level. Membership to group empowers farmers to obtain on time productive technology information and minimize transaction costs both on production process and output marketing through creating group sharing of cost and benefits. This finding is similar with Sebatta, Mugisha, Katungi, Kashaaru \& Kyomugisha (2014), they reason out that working in group creates collaboration among the farmers and enable them to access market information and sharing of best experiences together. Access to extension services is also shown expected sign and statistically significant at $1 \%$ level. This suggests that households, who had access to extension programs support, are more likely to intensify chemical fertilizer adoption on their teff cultivation than without contact.

Regarding the effect of the remaining variables, access to information, off-farm income availability, distance to town and age of head were statistically insignificant to influence the intensity of fertilizer with expected influence but nearby road condition shown unexpected negative sign.

\section{CONCLUSION AND POLICY IMPLICATION}

\section{Conclusion}

A remarkable improvement in agricultural Productivity in majority of developing countries in late 1960s resulted from agricultural Transformation agenda including of agricultural research, extension services and rural infrastructural development that basically underline the role technology adoption among smallholder's farmer in increasing production was vital. Technological change in agriculture comprises of introduction of high yielding variety of seeds, fertilizers, plant protection measures and irrigation. These changes in agricultural sector augment the productivity per unit of land and bring about rapid increase in production to tackle the severe problem of poverty. In Ethiopia, even though some progress has been recorded over time, the use of agricultural technologies special chemical fertilizer is found at its low level. To this end, this study was conducted with the aim of investigating the institutional, demographic and socioeconomic factors that influence the adoption decision and extent of chemical fertilizer among smallholder teff farmers. Accordingly, the descriptive statistics and Heckman two stage econometric methods were employed to analyze data collected from sampled household. The significance of coefficient of inverse Mill's ratio $(\lambda)$ indicates the presence of selection bias and the effectiveness of applying Heckman two stage model.

The adoption decision of chemical fertilizer use was driven by factors such as size of farm land, size of family, availability of family labor force, education status of 
household head, accessibility of credit service; access to modern technology information, distance to near town and nearby road condition. While the intensity of chemical fertilizer application was influenced by membership to cooperative, availability of extension service, access to credit, size of farm land, size of family member, the number of family labor force, educational status of house hold head, sex of head.

\section{Policy implication}

In light of these findings, Membership to a farmer group or cooperative being a crucial factor in enhancing the farmer technology adoption, it is suggested that policy makers should promote collective action among smallholders because it eases access to production, technology diffusion and marketing information as well as cheaper inputs. Moreover, the policies which expand the accessibility of credit service, dissemination of productive agricultural technology information, and creating opportunity of education for farm house hold has potential to increase the chance of chemical fertilizer adoption decision and strengthen the level of adoption among smallholder farmers.

\section{BIBLIOGRAPHY}

Ajayi, O.C., Franzel, S., Kuntashula, E., \& Kwesiga, F. (2003). Adoption of improved fallow technology for soil fertility management in Zambia: Empirical studies and emerging issues. Agroforestry Systems, 59(3), 317-326.

Bandiera, O., \& I, Rasul. (2005). Social Networks and Technology Adoption in Northern Mozambique.ll The Economic Journal, 116(514), 869-902.

Bayissa Gedefa. (2014). A double-hurdle approach to modeling of improved teff technologies adoption and intensity use: The case of Diga district of East Wollega Zone, Ethiopia. Global Journal of Environmental Research, 8(3), 41-49.

Beshir, H. (2014). Factors affecting adoption and intensity of use of improved forages in North East Highlands of Ethiopia. American Journal of Experimental Agriculture, 4(1), 12-27.

Beshir, H., Emana, B., Kassa, B. \& Haji, J (2012). Determinants of chemical fertilizer technology adoption in North eastern highlands of Ethiopia. Journal of Research in Economics and International Finance (JREIF), 1(2), 39-49.

Byerlee, D., Spielman, D., Dawit, A. \& Gautam, M. (2007). Policies to Promote Cereal Intensification in Ethiopia: A review of Evidence and Experience. IFPRI Discussion Paper 00707. Washington, DC.

Challa, M. (2013). Determining Factors and Impacts of Modern Agricultural Technology Adoption in West Wollega, Munich, GRIN Publishing GmbH, Available at: http://www.grin.com/en/e-book/280336/determiningfactors-and-impacts-ofmodern-agricultural-technology-adoption.

Cornejo, J. F., \& W. D. McBridge. (2002). Adoption of Bioengineered Crops.\| Agricultural Economic Report No. 810. Washington, DC 20036-583.

Debelo, D. (2015). Analysis of factors influencing adoption of quncho teff: The Case of Wayu Tuqa District. International Journal of African and Asian Studies, 12, 20-28.

Engdawork T. (2009). Understanding Teff: A Review of Supply and Marketing Issues . Ethiopia Commodity Exchange Authority, Addis Ababa.

Feder, G., Just, R.E \& Zilberman, D. (1985). Adoption of Agricultural Innovation in Developing Countries: A survey. Economic Development and Cultural Change, 33(2), 255-298

Greene W. H. (2003). Econometric Analysis, Fifth edition. New Jersey, 07458. USA: Pearson Education, Inc., Upper Saddle River, . 
Greene W. H. (2007). Econometric Analysis, sixth edition. New York, 07458. USA: Pearson Education, Inc., Upper Saddle River,.

Gujarati D. (1995). Basic Econometrics. Third edition. New York, USA.: McGraw Hill Book Company, Inc.

Heckman J. (1979). Sample Selection Bias as a Specification Error. Econometrica, 47, 153-161. http://dx.doi.org/10.2307/1912352.

Helder L. (2010). Adoption of Improved Maize And Common Bean Varieties In Mozambique; Michigan State University.

Holden, S. \& Lunduka, R. (2012). Do fertilizer subsidies crowd out organic manures? The case of Malawi. Agricultural Economics, 43(3), 303-314.

Ibrahim, A. A., Mustapha, S.B. \& Nuhu, S. H. (2012). Effects of Adoption of Rice Production Technologies on Farmers' Income in Borno State, Nigeria; Department of Agricultural Extension Services, University of, Maiduguri, Nigeria.

International Finance Corporation (IFC). (2013). Working with Smallholders A Handbook for Firms Building Sustainable Supply Chains; World Bank Group. World Bank.

Jain R., Arora A \& Raju S. (2009). A Novel Adoption Index of Selected Agricultural Technologies: Linkages with Infrastructure and Productivity: Agricultural Economics Research Review, 22, 109-120.

Japan International Cooperation Agency (JICA). (2012). The development study on the strengthening agricultural marketing system in South Nation Nationalities and Peoples regional state. Oversea Merchandise Inspection CO., LTD.

Kapalasa G.E. (2014). Assessing factors influencing farmers' adoption of improved soybean varieties in Malawi. Scholarly Journal of Agricultural Science, 4(6),339349.

Kothari. (2004). Research Methodology; Methods And Technique; Second Revised Edition. New Age International Publishers

Lavison R. (2013). Factors Influencing the Adoption of Organic Fertilizers in Vegetable Production in Accra, Msc Thesis, Accra Ghana.

Leake, G. \& Adam B. (2015). Factors determining allocation of land for improved wheat variety by smallholder farmers of northern Ethiopia. Journal of Development and Agricultural Economics, 7(3), 105-112.

Muzari, W. Gatsi, W \& Muvhunzi, S. (2012). The Impacts of Technology Adoption on Smallholder Agricultural Productivity in Sub-Saharan Africa: A Review. Journal of Sustainable Development, 5 (8), 69 - 77

Nkonya, E., T. Schroeder \& D. Norman,. (1997). Factors affecting adoption of improved maize seed and fertilizer in North Tanzania. Indian j. Agri.econ. 48(1),1-12.

Nowak PJ. (1987). The adoption of conservation technologies: Economic and Diffusion explanations. Rural social, 42, 208-220.

Ogada, M.J. (2013). Essays on Farm Technology Adoption, Technical Efficiency and Productivity In Smallholder Food Crop Agriculture In Kenya: Kenyatta University.

Ogada, M.J., Nyangena, W. \& Yesuf, M. (2010). Production Risk and Farm Technology Adoption in Rain-fed Semi-Arid Lands of Kenya. African Journal of Agricultural and Resource Economics (AfJARE), 4(2), 1-16.

Ray G.L. (2001). Extension communication and management. Second Edition. Naya Prokash, Calcutta

Sebatta, C., Mugisha, J. Katungi, E., Kashaaru, A. \& Kyomugisha, H. (2014). Smallholder Farmers' Decision and Level of Participation in the Potato Market in Uganda. Modern Economy, 5(8), 895-906. http://dx.doi.org/10.4236/me. 2014.58082 . 
Susie Teshome. (2017). Determinants of Adoption of Improved Teff Varieties by Smallholder Farmers: The Case of Kobo District, North Wollo Zone, Amhara Region, Ethiopia: Msc Thesis Haramaya University, Haramaya.

Tesfaye Ermias. (2013). Adoption of improved sorghum varieties and farmers' varietal trait preference: The case of Kobo District, North Wolo Zone, Ethiopia. MSc Thesis, Haramaya University, Haramaya, Ethiopia.

United Nation Environment Program(UNEF). (2013). Smallholders, food security, and the environment. the International Fund for Agricultural Development(IFAD) .

World Bank. (2008). Millennium Development Goals. Retrieved on 22rd Nov, 2012 from www.worldBank.org/mdgs/poverty-hunger.html. 